\title{
SUPPORTIVE LEADERSHIP AND ITS RELATIONSHIP TO ROA WITH COMMUNITY BANKS DURING THREE ECONOMIC TIME PERIODS
}

\author{
Gerald Sullivan, Keiser University, Ft. Lauderdale, Florida, U.S.A. \\ John Fitzgerald, Keiser University, Ft. Lauderdale, Florida, U.S.A. \\ Boris Djokic, Keiser University, Ft. Lauderdale, Florida, U.S.A.
}

dx.doi.org/10.18374/JIBE-20-1.4

\begin{abstract}
The purpose of the research is to determine if supportive leadership has an influence upon the financial performance of a company, in this case, Community Banks. Community Banks are generally locally owned; their stock is not traded on exchanges, and they have deposits of less than ten billion dollars. Community Banks in the southeastern United States were surveyed during three economic time periods (2003-2005, 2009-2011 and 2014-2016). Supportive Leadership, and its three components remain very important as managers and their staff hasten to identify problem assets, or potentially problem assets, by maintaining a high level of communication with the bank staff. This was found to be true in all three economics snap shots.
\end{abstract}

Keywords: Leadership styles, Supportive Leadership, Path-Goal Leadership theory, Situational Leadership Theory, financial performance, Return on Asset. 